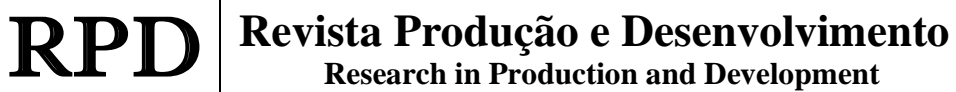

eISSN: 2446-9580

\section{RELATIONSHIP BETWEEN PROJECT GOVERNANCE, PROJECT PORTFOLIO AND BEST PRACTICES IN AN ENERGY TRANSMISSION COMPANY}

Vinícius Porto dos Santos Cruz ${ }^{1}$, https://orcid.org/0000-0001-6228-9266, viniciuspscruz@ hotmail.com

Fernando Oliveira de Araujo ${ }^{1}$, https://orcid.org/0000-0003-3716-0844, fernandoaraujo@id.uff.br

1 Fluminense Federal University, 24210-200, Niterói-RJ, Brazil

\section{Submitted: 07/10/2021. Accepted: 18/11/2021}

Published: 06/12/2021

\begin{abstract}
Purpose: This article aims to investigate how project governance, project portfolio management and best practices are related in a company in the Brazilian electricity sector, considering the gaps identified in the management of its projects and the results of them. Methodology/Approach: In order to subsidize this study, in theoretical terms, the study is supported by a systematic survey of the literature and, in empirical terms, it conducts an investigation with 18 key employees of the organization through the application of a questionnaire, with a view to confronting the perception of respondents with the relevant concepts found in the literature. Findings: In the empirical research, on the other hand, made it possible to investigate the perception of respondents from different groups in relation to the organization's adherence to the proposed themes. Research Limitation/implication: The studies were not carried out outside the environment of the selected company, nor are extrapolations made to other organizational realities, although it recognizes that this study can contribute to influencing companies in the same or different segment to deepen into the above theme. Originality/Value of paper: The proposed research is applicable in all organizations or sectors that are strategically project oriented.
\end{abstract}

KEYWORD: projects, management, governance, project management office, portfolio, best practices.

\section{RELACIONAMENTO ENTRE GOVERNANÇA DE PROJETOS, CARTEIRA DE PROJETOS E MELHORES PRÁTICAS EM UMA EMPRESA DE TRANSMISSÃO DE ENERGIA}

\section{RESUMO}

Objetivo: Este artigo tem como objetivo investigar como governança de projetos, gerenciamento de portfólio de projetos e melhores práticas se relacionam em uma empresa do setor elétrico brasileiro, considerando as lacunas identificadas na gestão de seus projetos e os resultados dos mesmos. Metodologia: Com o objetivo de subsidiar este estudo, em termos teóricos, o estudo é apoiado por um levantamento sistemático da literatura e, em termos empíricos, realiza uma investigação com 18 funcionários-chave da organização através da aplicação de um questionário, com o objetivo de confrontar a percepção dos respondentes com os conceitos relevantes encontrados na literatura. Resultados: Na pesquisa empírica, por outro lado, foi possível investigar a percepção dos respondentes de diferentes grupos em relação à aderência da organização aos temas propostos. Limitação da pesquisa: Os estudos não foram realizados fora do ambiente da empresa selecionada, nem são feitas extrapolações para outras realidades organizacionais, embora se reconheça que este estudo pode contribuir para influenciar empresas do mesmo ou de diferentes segmentos a se aprofundarem no acima tema. Originalidade: A pesquisa proposta é aplicável em todas as organizações ou setores que são estrategicamente orientados para projetos.

PALAVRAS-CHAVE: projetos, gerenciamento, governança, escritório de gerenciamento de projetos, portfólio, melhores práticas. 


\section{INTRODUCTION}

With the promotion of the restructuring of the Brazilian Electric System in the late 1990s, the concession model in the electricity transmission segment became competitive, allowing private and state companies, with national or foreign capital, in the form of consortium or not, could dispute the concession of this public service (Cazzaro, 2017). Since then, the current transmission expansion model has been based on auctions for concession contracts where companies responsible for the construction, operation and maintenance of transmission facilities for 30 years are chosen (Paulo, 2012). According to ONS data (2021), prior to the aforementioned auctions, the transmission line infrastructure installed in Brazil was approximately 64.000 kilometers long. In 2020, the extension of available transmission lines was 145.600 kilometers, with plans to reach the extension of 184.054 kilometers by the year 2025. These numbers indicate that in the last 20 years, the available infrastructure has more than doubled in size through the auctions, with the prospect of being close to tripling its capacity by 2025 .

For this reason, the opening of the transmission market has provided a new dynamic to the sector since then: i) the expansion of the transmission system leveraged the demand for projects in the segment, which are the main means for companies to achieve their strategic goals; and ii) in order to execute multiple projects, it is relevant to establish practices and processes for project management in order to create and manage organizational knowledge, whether for regulatory, technical or strategic reasons, given the competitiveness imposed by the market.

These referred processes comprise the best practices and management methods represented by tools and techniques adopted by professionals to perform project management activities (Tereso et al., 2019; Shou et al., 2021; Barbosa et al., 2021). In this regard, it is important to emphasize that such processes are directly related to the organizational context, business model and sector, company size and the environment in which it operates (Kwak et al., 2015; Tereso et al., 2019).

Regarding the management of its projects, a company may be organized in 03 levels: the highest hierarchical level represented by bodies oriented to the determination of a project policy and strengthening of its practices (project governance), the middle organizational management of each cluster responsible for managing multiple projects under implementation (project portfolio) and a manager for each project, who can be responsible for executing them (Lappi et al., 2019; Martinsuo $\&$ Geraldi, 2020). In addition to this structure, the organization can have a Project Management Office (PMO) whose objective should be transiting between all levels, developing and disseminating knowledge in project management (Kwak et al., 2015). According to Müller et al. (2019), the correlation and synergy between best practices and project management processes, the project portfolio and project governance are essential elements for the achievement of objectives and the proper functioning of project management in organizations.

In this regard, this study aims to seek answers to the following question: "From the perspective of its professionals and supported by what the literature recommends, how the elements - Project Governance, Project Portfolio and Best Practices - are related in the organization under this study?". Then, this article aims to investigate how project governance, project portfolio management and best practices are related in a company in the Brazilian electricity sector, considering the gaps identified in the management of its projects and the results of them, and how the 03 themes apply in the organization and to propose solutions for their improvement through the identified problems.

In terms of organization, the study is subdivided into five distinct sections, the first being the one that offers the context of the theme, in addition to highlighting the research problem and the objective of this study. Section 2 summarizes results from the literature review, bringing up the main concepts and foundations capable of supporting the field investigation and its results. Section 3 describes the methodological procedures of the empirical research through the application of a questionnaire with the company's key employees. Section 4 analyzes and discusses the results of the empirical investigation. In the fifth and last section the conclusions about the study are described. 


\section{LITERATURE REVIEW}

\subsection{Project Governance}

Project governance embraces policies, processes and organizational entities that are responsible for defining roles and responsibilities, coordinating the relationship with the stakeholders and defining the decision hierarchy in projects so that they fulfill their objectives. (Müller et al., 2014; Too \& Weaver, 2014; Ul Musawir et al., 2017; Derakhshan et al., 2019; Lappi et al., 2019; Müller et al., 2019). Governance is a management function for establishing policies capable of overseeing and ensuring the execution of a company's objectives according to the organizational level where it is adopted, whether a single or multiple projects managed collectively (Müller et al., 2014; Müller et al., 2017; Müller et al. 2019).

The implementation of project governance takes place via organizational facilitators called governance institutions, such as steering committees, Project Management Offices (PMO) or any other project authority that has a role in complying with it, and vary according to the type of project, sector and degree of adherence to projects by the organization (Müller et al., 2014; Müller et al., 2019). According to Müller et al. (2014), the governance mentality in organizations represents their way of thinking about governance in different approaches according to each task and established governance level. For Ul Musawir et al. (2017), this mentality is the result of the adoption of governance principles by the project authorities and an incorporation of the responsibilities concerned, since project governance influences the project's success.

A relevant aspect in the organizational structure of a company that can impact its projects is its design of decision hierarchy and relationships (Petro \& Gardiner, 2015). The active posture of leaders in decisions must observe the context in which a single project or multiple projects are found, so as not to sabotage the macro-objective of the organization's business (Petro \& Gardiner, 2015; Tavares, 2015). According to Hermano and Martín-Cruz (2016), top management must shape the institutional context, become a provider of results and provide teams with an environment that promotes the success of projects. For Bekker (2014), the differences in governance approaches are more motivated by the complexity of the stakeholders than by the project's complexity, as they also have a direct influence on the results.

Stakeholders are the entire community of the organization's projects that are key elements for its success (Patanakul, 2015). In this regard, decision-making by the sponsors requires a deep analysis regarding the risk-taking posture in relation to the expected return on investments, the selection of the best projects and the respective allocation of resources according to the strategy, influence of stakeholders and the business ethics that compose the company's values (Bekker, 2014; Too \& Weaver, 2014; Hermano \& Martín-Cruz, 2016; Derakhshan et al., 2019).

\subsection{Project Portfolio Management}

Project portfolio management is a project management technique adopted to align and control a group of projects according to the objectives and benefits expected by an organization (Lappi et al., 2019). This technique has become relevant over the years, being a fundamental competence to conduct multiple projects simultaneously (Kock \& Gemünden, 2019). In the literature, portfolio management is established as the application of practices and tools for the collective management of projects in order to execute an organization's global strategy through the link between projects, programs and portfolio (Patanakul, 2015; Petro \& Gardiner, 2015; Oosthuizen et al., 2016; Kock \& Gemünden, 2019; Müller et al., 2019; Martinsuo \& Geraldi, 2020).

However, project portfolio management cannot be limited to managing only its projects, given its direct relationship with the strategic goals and internal and external contexts of organizations (Martinsuo \& Geraldi, 2020; Arabomen et al., 2021). The structuring of a portfolio 
that adheres to the strategy embraces the steps of mapping alternatives, categorizing, evaluating, prioritizing, balancing and authorizing projects (Patanakul, 2015; Martinsuo \& Geraldi, 2020).

According to Petro and Gardiner (2015), maintaining a balanced portfolio that adheres to the business strategy results from the wide variety of possible combinations of projects that make up a portfolio under structural constraints and other of the organization itself. Among the situations to be observed in the selection and management of these projects, the interdependence and coordination between projects, resource sharing, operational capacity, support from sponsors and relationship with stakeholders stand out in the literature (Clegg et al., 2018; Derakshan et al., 2019).

For Tavares (2015) and Petro and Gardiner (2015), the project portfolio must be temporarily revisited according to the changes in priorities and organizational limitations imposed on its execution, as the selection and maintenance of these projects will take place by the direction of the objectives and not by the similarities of their natures. In this regard Patanakul (2015) mentions that effective portfolio management encompasses: 1) alignment with the organization's strategy; 2) adaptation to internal and external changes; 3) selection of projects with high value or benefit; 4) project visibility to stakeholders; 5) transparency and ethics in decision making and; 6) predictability of project performance.

The assessment of organizational performance arises from the need to establish links between planning, decision, action, and result (Silva et al., 2021). Therefore, a robust evaluation process, prioritizing and measuring the expected benefits supported by project governance, allows organizations to maximize their returns on investments and supports the achievement of their goals (Petro \& Gardiner; 2015; Ul Musawir et al., 2017).

\subsection{Organizational Best Practices}

The change in the organizational structure of companies is linked to the turmoil of the internal and external environments, risks and uncertainties of their businesses and how such circumstances result in adaptations and/or changes (Patanakul, 2015; Hermano \& Martín-Cruz, 2016). The variability in organizational activities arising from the aforementioned scenarios, requires a governance role in sponsoring the projects to be affected, promoting flexibility in their management in order to address the necessary changes. (Patanakul, 2015; Hermano \& Martín-Cruz, 2016). In this regard, according to Petro and Gardiner (2015) and Patanakul (2015), the organizational structure has a direct effect on the portfolio's success because the greater the adaptability to internal and external changes, the greater the effectiveness in managing the project portfolio.

The implementation of an adaptable and effective management system results in a change in the company's culture and management (Lachowski, 2016). Many authors indicate practices for managing projects, programs and portfolios that comprise routine management activities established through conceptual models, processes and procedures (Oliveira et al., 2017; Clegg et al., 2018; Müller et al., 2019). For Oosthuizen et al. (2016) and Clegg et al. (2018), one of the greatest benefits of a project, program and portfolio management system at the organizational level, when well implemented, is to provide accurate information about projects and objectives to support decision-making by governance.

The organizational entity with the greatest adherence to these assignments is the Project Management Office (PMO) (Too \& Weaver, 2014; Müller et al., 2019; Echcharqy, 2020; Fernandes et al., 2020; Fernandes et al., 2021). There are several ways to classify the PMO in the literature. PMO can be seen as an internal consultancy with high experience in project management for the application of standards and processes (Too \& Weaver, 2014), a vector of excellence in project management and decision support (Arduino, 2015), an organizational unit responsible for structuring, managing and implementing the selected projects (Lachowski, 2016), an internal entity for coordinating and streamlining project portfolio management (Bredillet et al., 2018); and an 
organizational agent with knowledge in project management (Rezende \& Cordeiro, 2020). For Too \& Weaver (2014), an effective EGP supports the good governance of the project, ensuring that information in its reports is relevant, accurate and complete, providing enough support to the governance to support decision making.

\section{MATERIAL AND METHODS}

\subsection{Characterization of research subjects}

This work aims to analyze the strategic and tactical scopes of managing the project portfolio of an organization in the electricity sector. Therefore, the research subject addresses the motivation for this when these respondents are identified and qualified. The defined groups are presented in Table 01.

Table 01: Classification of research subjects by groups (Elaborated by authors)

\begin{tabular}{|c|l|l|c|}
\hline$\#$ & \multicolumn{1}{|c|}{ Groups } & \multicolumn{1}{|c|}{ Description } & Quantity \\
\hline $\mathbf{1}$ & $\begin{array}{l}\text { Operational level in } \\
\text { project management }\end{array}$ & $\begin{array}{l}\text { Responsible for applying management tools and processes at the } \\
\text { level of projects and programs in the organization. }\end{array}$ & 5 \\
\hline $\mathbf{2}$ & $\begin{array}{l}\text { Operational level in } \\
\text { portfolio management }\end{array}$ & $\begin{array}{l}\text { Responsible for applying management tools and processes at the } \\
\text { portfolio level in the organization }\end{array}$ & 2 \\
\hline $\mathbf{3}$ & $\begin{array}{l}\text { Managerial level in } \\
\text { project management }\end{array}$ & $\begin{array}{l}\text { Responsible for the direct management of projects that make up } \\
\text { the organization's portfolio. }\end{array}$ & 6 \\
\hline $\mathbf{4}$ & $\begin{array}{l}\text { Functional managerial } \\
\text { level }\end{array}$ & $\begin{array}{l}\text { Responsible for supporting the execution of projects that } \\
\text { composes the organization's portfolio. }\end{array}$ & 2 \\
\hline $\mathbf{5}$ & $\begin{array}{l}\text { Strategic level in portfolio } \\
\text { management }\end{array}$ & $\begin{array}{l}\text { Responsible for the organization's strategic guidelines reflected } \\
\text { in the portfolio. }\end{array}$ & 2 \\
\hline $\mathbf{6}$ & Institutional level & Head of the organization & 1 \\
\hline
\end{tabular}

Figure 01 illustrates a conceptual organization chart of the groups that composes the organization's sample and their respective quantities.

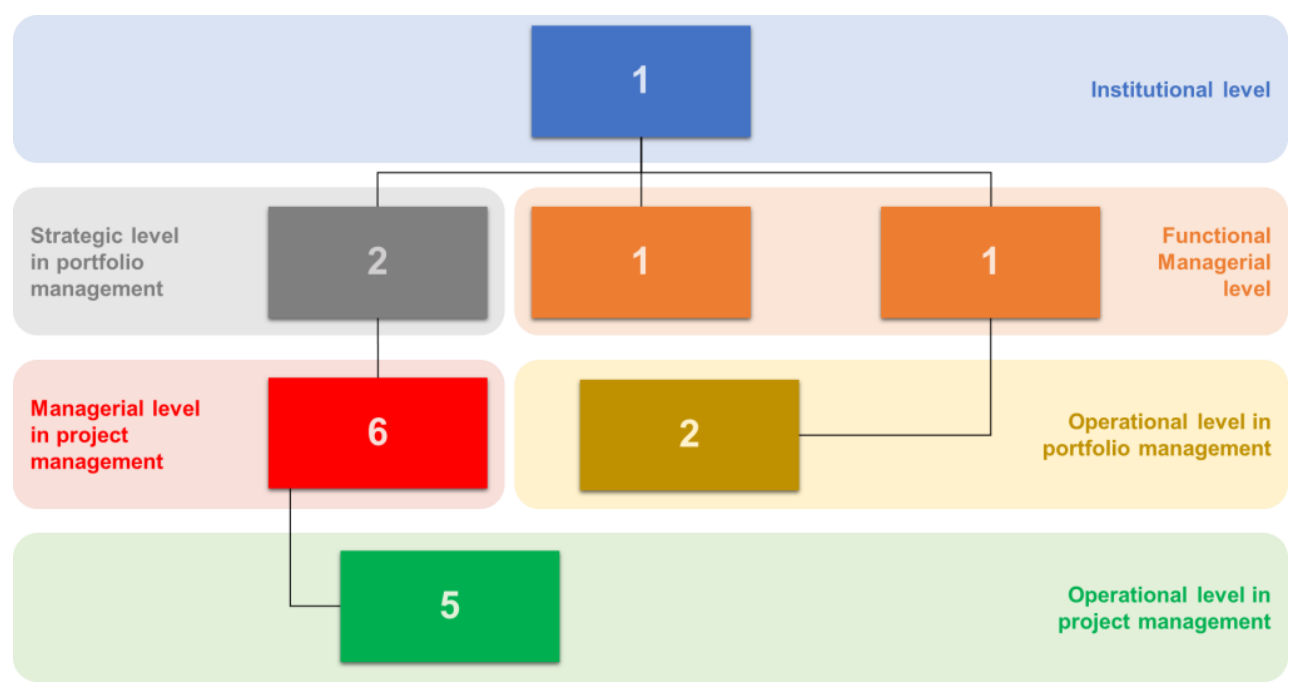

Figure 01: Conceptual organization chart of the research subjects (Elaborated by authors) 


\subsection{Data gathering}

First, data gathering was carried out from bibliographic research for secondary sources. Data were obtained through a bibliometric survey, using the keywords presented in the databases. Then, based on the relevant literature, a script was developed to gather data from primary sources, carried out through a questionnaire applied in the company under study. The procedure was applied to the groups defined in Section 3.1.

The forms were previously delivered to the groups and the most relevant topics of the research, its purpose, objectives, relevance and the key points of the questionnaire were also presented, according to Marconi \& Lakatos (2003). Thus, the aforementioned questionnaire was used as a guide to diagnose the organization under study. The instrument was designed considering the research objectives, the theoretical support from the literature and the heterogeneity of the respondents' profile.

\subsubsection{Instrument validation procedure}

For this study, a pre-test was carried out, according to Marconi \& Lakatos (2003), which involved the application of the questionnaire with 03 professionals from the energy transmission sector who are not part of the mentioned organization, between the 28th of October 2019 and November 4, 2019. Among the professionals mentioned, 02 occupy managerial positions that similarly fit into Group 3 - Managerial level in project management and 01 occupy a specialist position that similarly fits into Group 1 - Operational level in project management as defined in Section 3.1 of this paper. The adoption of the pre-test contributed to the optimization of the questionnaire and the elaboration of questions with greater adherence to the profile of professionals working in the sector, aiming at greater participation by respondents.

\subsection{Data analysis procedures}

The evidence of this work includes the bibliographical review, data from the studied organization and application of the questionnaire with key professionals directly involved in the management of the company's projects. The present study makes use of the triangulation of these data, in order to compare its results.

Thus, it was possible to seek convergence and divergence between the specialized literature (secondary sources) and the perception of professionals who experienced the phenomenon object of study (primary sources). Considering the nature of the quali-quantitative instrument, descriptive statistical techniques were adopted to allow the identification of individual responses from each of the 18 respondents.

In the subsequent section, comparative analyzes of the respondents were carried out and, in order to highlight possible ambiguities and corroborate the proposed analyzes regarding the level of adherence to the literature, lexicography techniques were adopted based on the answers provided in the open questions.

\section{RESULTS}

\subsection{Respondent's profile}

Eighteen respondents with different profiles, roles and responsibilities in the company, and who worked in the implementation of transmission projects, participated in the survey through the application of 18 questionnaires in the period between November 6 and 13, 2019. To choose the respondents, the criterion of professional experience in project management, their main attributions in the organization and their availability to participate in the research was adopted. Of the 18 
questionnaires applied, 06 were carried out through personal contact between the researcher and the respondent. As for the 12 others, contact had been made by email. The profile of respondents obtained through the application of the data collection instrument is presented in Table 02 below, as shown in Section 3 of this paper.

Table 02: Identification of the profile of respondents (Elaborated by authors)

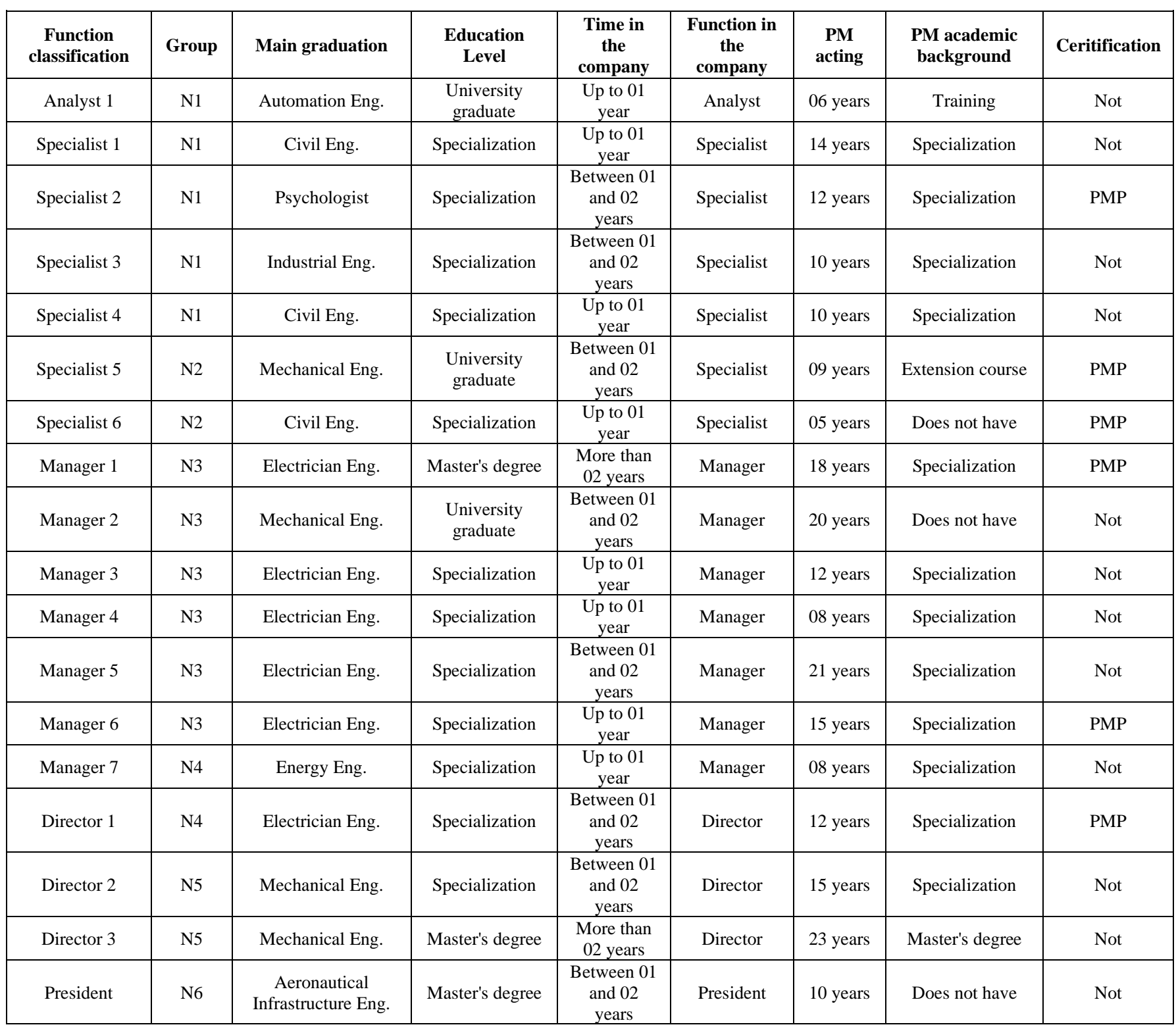

\subsection{Discussion}

The empirical research identified the respondents' perception of the organization when analyzed from the perspective of what the scientific literature advocates for Project Governance, Project Portfolio Management and Organizational Best Practices. This questionnaire consists of 10 questions about each theme, 01 of them open and the other 09 closed. The closed questions were parameterized by a Likert scale from 1 to 5, where 1 represents the criterion strongly disagree and 5 strongly agree, in relation to the theoretical propositions presented.

\subsubsection{Project Governance}

The proposals presented in the questionnaire investigated the following themes found during the literature review: a) governance principles and mechanisms for decision making; b) leadership 
performance; c) governance mentality about functions and structure; d) alignment with corporate governance and; e) stakeholder management. Figure 02 illustrates the responses of the groups within these contexts.

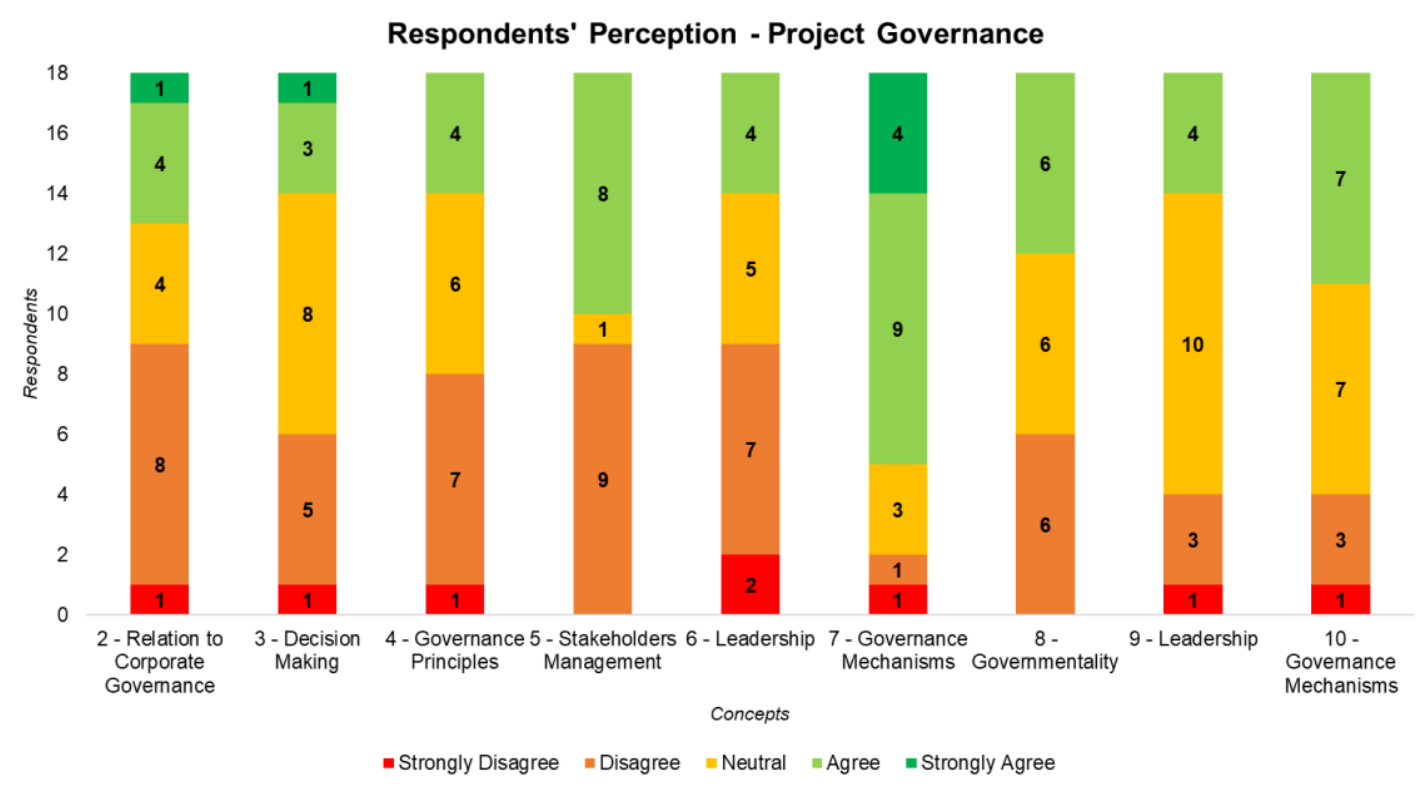

Figure 02: Respondents' Perception of Project Governance (Elaborated by authors)

It was possible to infer from the data presented a heterogeneity in relation to the employees' perception. The greatest adherence to what is recommended in the literature is seen in the concepts related to Governance Mechanisms, while those that represent the least adherence are Relation to Corporate Governance, Governance Principles and Leadership. The other themes present a balance in their perceptions; however, they reinforce the dissonant character of the respondents in relation to the company under study.

In general terms, less adherent perceptions suggest gaps in the dissemination of governance principles and procedures throughout the organization, in addition to project management. Furthermore, it could be seen that the role of the steering committee in the deployment of the strategy is not understood by most respondents, with failures in communication and establishment of the company's objectives.

The perception of Expert 5 in his answer corroborates the above:

Governance is not widespread outside the project scale. Yet the framework works very well within each project when viewed individually. Little influence with support areas and limited action at the portfolio level.

Despite the respondents recognizing the organizational existence of facilitators who should be the precursors of governance policies, the conceived strategy is questioned, suggesting the absence of processes, lack of clarity and criteria for decision-making. In this regard, the biggest gap indicated by the respondents is the absence of a unit as commented by Manager 3:

I understand that project governance is well structured, despite the fact that there are divergences in standardization and in concept between the various departments about how the project management model should be [...].

\subsubsection{Project Portfolio Management}

About this concept, we sought to evaluate the following concepts identified in the literature: a) practices adopted to define the strategy; b) systems and criteria for project selection and 
prioritization; c) optimization and allocation of resources in projects; d) performance of projects in the realization of benefits and; e) competitive advantage. The results are shown in Figure 03.

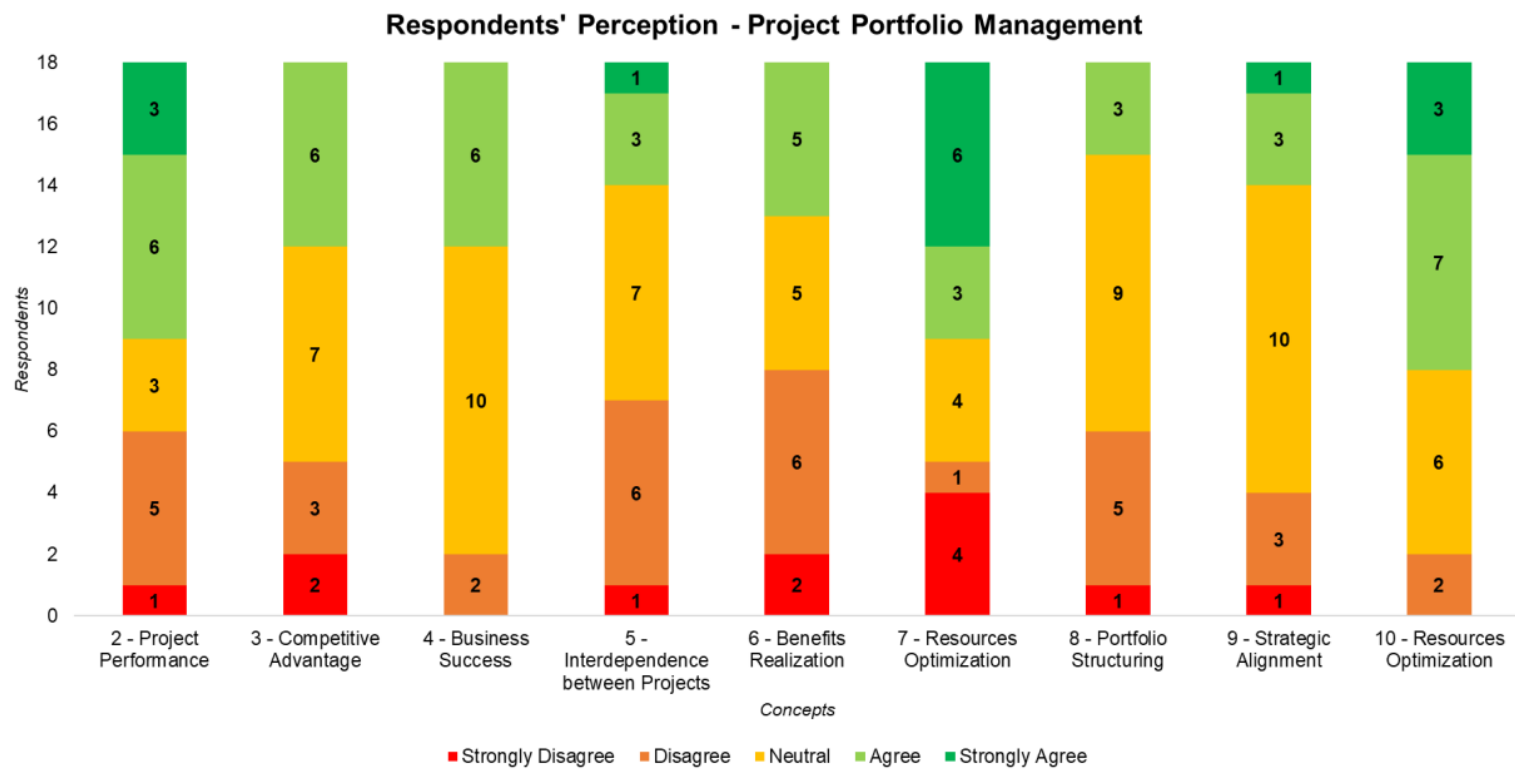

Figure 03: Respondents' perception of Project Portfolio Management (Elaborated by authors)

In this section there was also a dissonance in the respondents' perception. As shown in the chart, the concepts with greater adherence are Project Performance, Business Success and Resource Optimization. The ones that show less adherence are Interdependence between Projects, Realization of Benefits and Portfolio Structuring.

The results indicate that the respondents did not identify formal processes for structuring the project portfolio as indicated in the literature, as well as the alignment between the strategy and its execution.

An ambiguity was also identified between the open and closed questions regarding two concepts that were well evaluated in the respondents' perception: Resource Optimization and Project Performance. It is considered here that open questions have greater relevance in terms of ambiguity and, therefore, as much as the company had the necessary resources for its portfolio and shared them, the fact was due to the excess of resources and not the correct allocation with the needs of the company in time.

The answer of the President of the organization reinforces this understanding:

The system was poor in the aspect of not adequately forecasting all the resources needed to carry out the projects in time, where the ambition of the growing portfolio was realized in the concept of abundance of resources, which is now beginning to be corrected.

Regarding performance, which represents the ability to manage projects through a formal management system, there is no agreement among respondents if the system is able to provide competitive advantage and manage the benefits of projects, given the position of Director 2:

There is a project portfolio management system, but it is aimed to meet the demand of the company's senior management and not acting as a beacon of the projects, addressing the best paths to be taken and working with support and partnership.

\subsubsection{Organizational Best Practices}

Finally, the propositions about this element investigated the following themes: a) processes, tools and best practices for project management; b) organizational structure with definition of roles 
and responsibilities; c) organization and standardization of management and; d) Project Management Office (PMO). Figure 04 illustrates the results obtained.

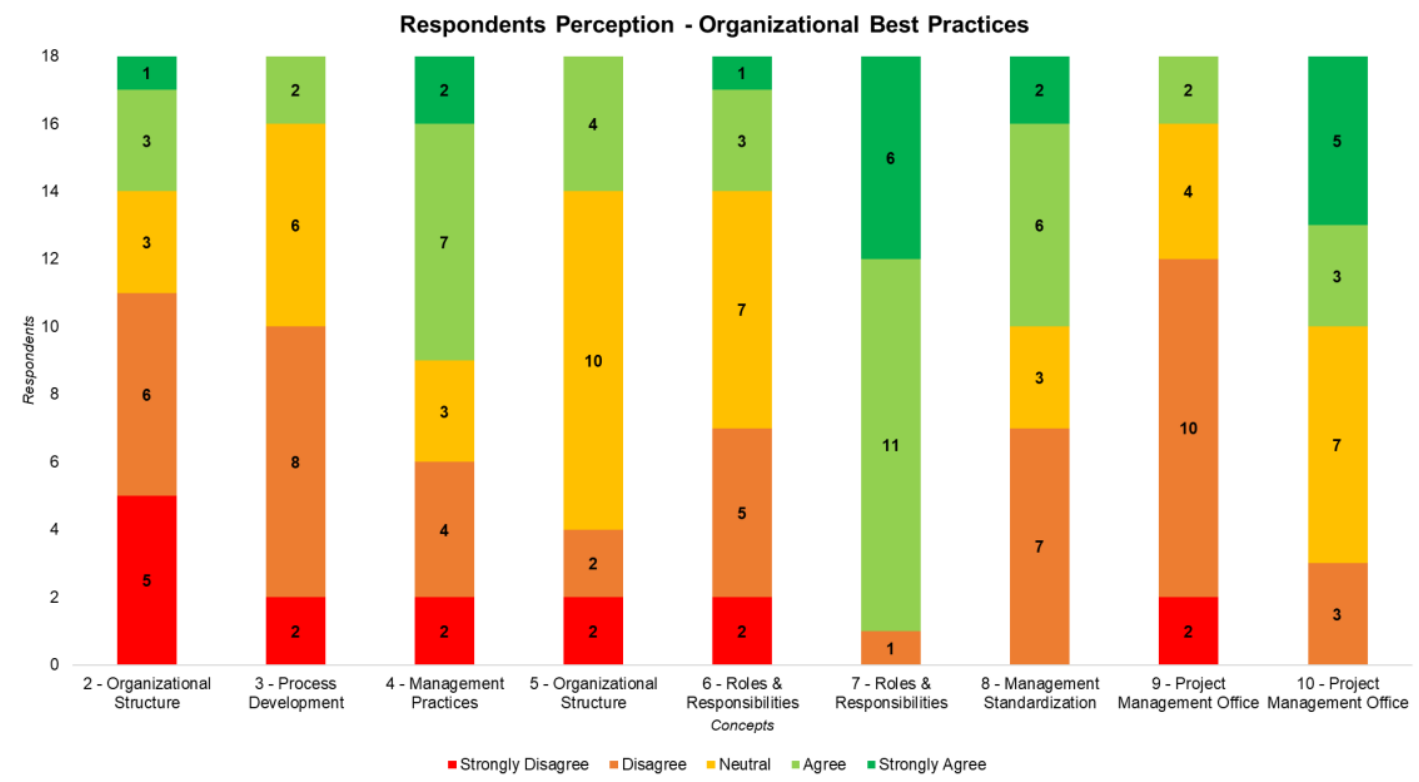

Figure 04: Respondents' perception of Organizational Best Practices (Elaborated by authors)

As with the other central themes, there was heterogeneity in the responses, however, with more adherent aspects than the others. Regarding adherence to the literature, the topic that presented the best performance was Management Practices, while the worst performance was Organizational Structure and Process Development. Roles and Responsibilities and Project Management Office were evaluated positively and negatively from different perspectives.

The management practices, despite not being integrated and being distinct between the clusters, were considered adherent because they reach the objectives to which they were adopted, even if individualized. However, with regard to the PMO, the respondents' perception is different. The same does not corroborate the definitions in the literature that indicate its role in the integration and dissemination of knowledge for the organizational project management. This position was reinforced by Manager 1:

After the first 12 months, stakeholders began to converge on what they understand as governance and then governance began to be planned by the PMO area. Currently, the PMO fails to communicate the governance defined by the company's management to all areas.

The biggest problem identified by the respondents was in the organizational structure of the company, where everyone elucidated an identity crisis in what represents the company's core business, directly impacting the development of its processes and delegation of responsibilities. The aforementioned crisis was exposed by the President of the organization:

Until recently, the organization experienced an identity crisis of its real business model, with this, the entire organization of the company was designed within an imagined model, a model that is still being redefined, which causes there to be a corporate schizophrenia between who we are and how we organize ourselves. This process is accentuated by the diversity of leadership profiles hired by the company. This last element makes it difficult to diagnose the problem, are we a transmission company, are we project developers, are we an EPC company? 


\subsection{Action proposals for the organization under study}

Considering the results presented in the sections above, a series of action proposals based on the relevant literature were established, aiming to improve the systematic adopted by the studied company for the management of its projects. Such proposals are presented in the matrix of effort $\mathrm{x}$ impact illustrated in Figure 05.

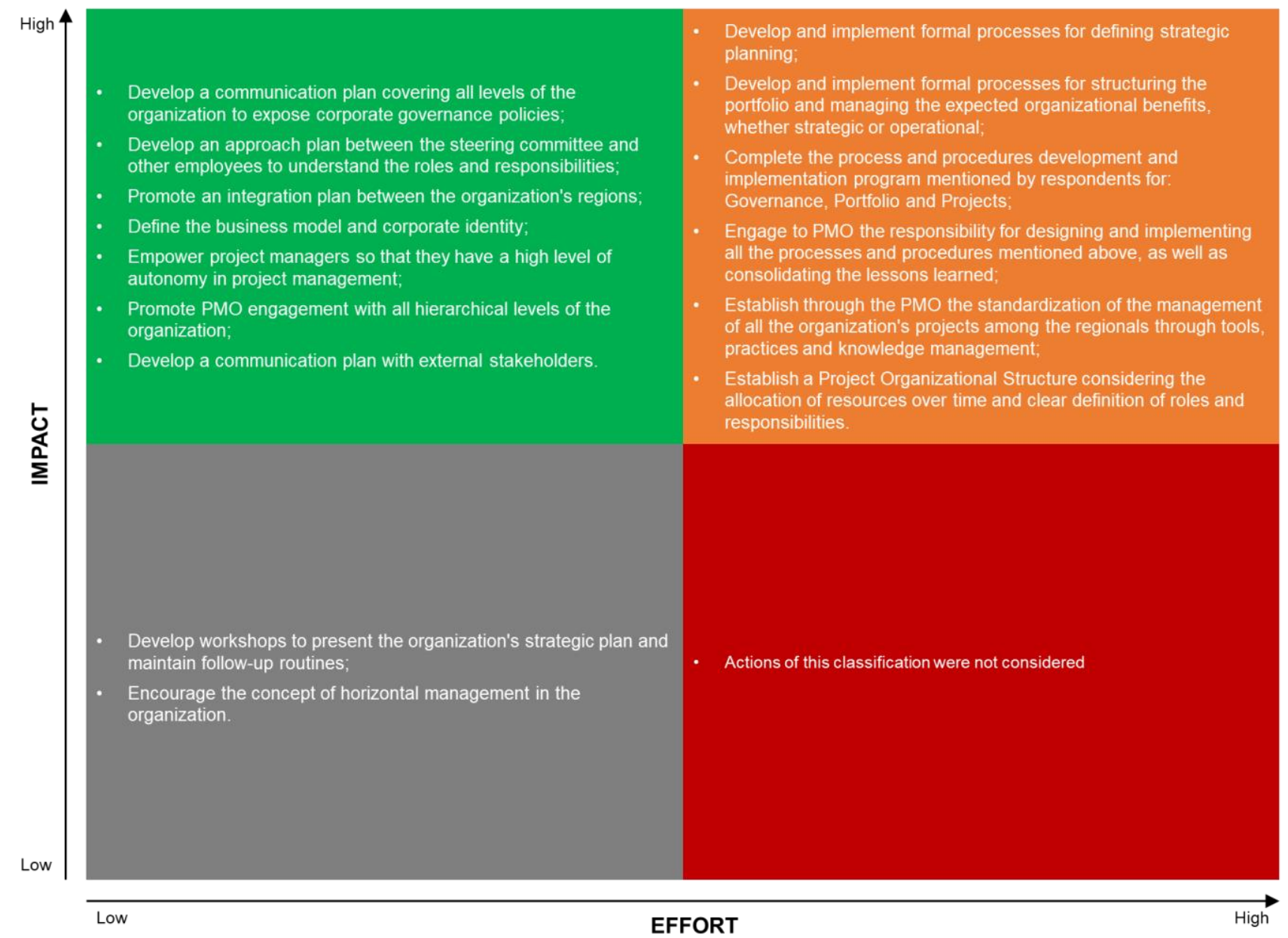

Figure 05: Matrix of effort $\mathrm{x}$ impact for the actions proposed to the organization studied (Elaborated by authors)

As previously stated in Section 4 of this study, the gap between what the literature advocates and what is practiced by the organization is due to the respondents' perception regarding the deployment of their strategy, organizational identity, lack of clarity in setting goals and in proposing a horizon for your business.

During the analysis of the results, it was observed that the main factors that result in such distance are: a) failure in communication between the steering committee and the other hierarchical levels of the company in relation to the perception of organizational strategy and definition of roles and responsibilities; b) the lack of portfolio integration in order to establish a single methodology throughout the company; c) the identity crisis of the organization's EGP in view of its functions; and, finally, d) absence of formal processes and procedures for managing their projects.

It is expected that, with these actions, the steering committee assumes the prominent role given to it in decision-making and strategy preparation (Mosavi, 2014; Hermano \& Martín-Cruz, 2016), in order to contribute directly to the result of projects, to engage stakeholders and influence the realization of expected tangible and intangible benefits (Hermano \& Martín-Cruz, 2016; Martinsuo \& Geraldi, 2020). 
In this regard, based on the influence of top management, it is believed in the establishment of favourable conditions for the implementation of governance policies capable of proposing a portfolio management system that adheres to the objectives and structure of the company under study (Müller et al., 2014; Müller et al., 2017; Müller et al. 2019). Consequently, the adoption of this system tends to integrate the management of multiple projects in a coordinated manner, including common practices and procedures (Clegg et al., 2018; Derakhshan et al., 2019). The role of the PMO in this regard is extremely valuable in establishing unique processes, procedures, tools and management techniques at all organizational levels, in order to establish a standardized methodology, identified as one of the most relevant gaps by respondents. According to Bredillet et al. (2018) and Rezende \& Cordeiro (2020), the PMO is an entity with knowledge in project management responsible for structuring, managing and implementing management best practices.

The steering committee and the PMO are the main organizational facilitators within the company's governance structure for the success of the suggested action and improvement plan (Müller et al., 2014; Müller et al., 2017). The actions described in Figure 05 are based on activities guided by business communication and operational work for the development of the suggested procedural framework. With regard to communication, it is believed that these activities can be carried out in the short term, through the engagement of senior management and company resources.

On the other hand, for the establishment of the entire necessary procedural framework, it is understood that such actions are feasible in the medium and long term, given the need for additional efforts for the development, implementation, training and maturation of a unique methodology that will affect the structural and cultural aspects of the organization. Therefore, it is expected that the gaps identified by the respondents are filled with all or most of the proposed organizational improvement actions given the latent demands for the fulfilment of the strategy.

\section{CONCLUSION}

This research had as objective to carry out an empirical investigation in an organization of the electric sector, in order to know how 03 key elements related to the accomplishment of the objectives and the good functioning of the project management according to Müller et al. (2019) Project Governance, Project Portfolio and Best Practices - considering the problems mentioned in Section 1 of this paper. This investigation was carried out through the application of a questionnaire with 18 respondents who made up the staff of the organization under study, have significant qualifications and played relevant roles in managing the project portfolio. They were divided into groups according to their function and field of action.

The instrument was built based on the literature, specifically relevant works on the 03 central themes, aiming to investigate the perception of each respondent regarding the main concepts identified. Although the answers were heterogeneous in form, it was possible to consolidate them through the use of descriptive statistics and combined qualitative techniques to assess the degree of adherence of the company.

In the discussion of the results, there was a considerable gap between what the literature advocates and what is perceived by the survey respondents as set out in Section 4. Specifically, the main issues of withdrawal are the functions of the PMO, the organizational identity crisis and the role of senior management in materializing the strategy. These points were presented by respondents as the crucial elements that triggered the other problems listed.

At the end of the discussion, actions for the company were presented based on what the literature recommends in the form of a matrix of effort $\mathrm{x}$ impact, classified according to their relevance, in order to provide improvements in the means by which the company managed its projects in view of the respondents' perception. 
The present study is limited to verifying the relationship of the key concepts in project management, as mentioned above, of only one organization in the electricity sector. Therefore, only the organization's employees compose the respondent framework, guiding a perception of a single organizational context.

Considering the above mentioned, for future studies, it is suggested that similar research be carried out in other organizations in the same sector or different sectors, in order to identify possible divergences or convergences between organizations or sectors. In addition to the above, it is recommended to increase the procedural framework listed in Figure 5 to allow for a future analysis of the company's project management approach, given the divergences identified by the respondents when confronted with the specialized literature.

Finally, it is possible to conclude that the general objective of this study was achieved, considering the analysis of the organization's adherence to what is recommended in the literature through the participation of its key collaborators and the aforementioned proposed actions.

\section{REFERENCES}

Arabomen, O. J., Babalola, F. D., Idumah, F. O., \& Ofordu, C. S. (2021). Residents' attitudes towards tree care programs in cityscapes. Revista Produção e Desenvolvimento, 7. https://doi.org/10.32358/rpd.2021.v7.462

Arduino, E. G. A. (2015). Success vector: approach of a PMO in the electrobras system. Thesis (Master in Management Systems). Niterói: Federal Fluminense University, 2015. Advisor: Prof. PhD José Rodrigues de Farias Filho.

Barbosa, A. P. F. P. L., Salerno, M. S., de Souza Nascimento, P. T., Albala, A., Maranzato, F. P., \& Tamoschus, D. (2021). Configurations of project management practices to enhance the performance of open innovation R\&D projects. International Journal of Project Management, 39(2), 128-138. https://doi.org/10.1016/j.ijproman.2020.06.005

Bekker, M. C. (2014). Project governance: "Schools of thought". South African Journal of Economic and Management Sciences, 17(1), 22-32. https://doi.org/10.4102/sajems.v17i1.595

Bredillet, C., Tywoniak, S., \& Tootoonchy, M. (2018). Why and how do project management offices change? A structural analysis approach. International Journal of Project Management, 36(5), 744-761. https://doi.org/10.1016/j.ijproman.2018.04.001

Cazzaro, P. M. (2017). Analysis of investor dynamics in electricity transmission auctions in Brazil between 1999 and 2017. Thesis (Masters in Science) - Institute of Energy and Environment. São Paulo: University of São Paulo, 2017. Advisor: Prof. PhD Virginia Parente.

Clegg, S., Killen, C. P., Biesenthal, C., \& Sankaran, S. (2018). Practices, projects and portfolios: Current research trends and new directions. International Journal of Project Management, 36(5), $762-772$. https://doi.org/10.1016/j.ijproman.2018.03.008

Derakhshan, R., Turner, R., \& Mancini, M. (2019). Project governance and stakeholders: a literature review. International Journal of Project Management, 37(1), 98-116. https://doi.org/10.1016/j.ijproman.2018.10.007

Echcharqy, S. (2020). Project Management Office (Pmo) For Strategy Alignment: Case Of The Ministry Of Industry, Trade, Green And Digital Economy In Morocco. Management \& Marketing Journal, 18(2).

Fernandes, G., Pinto, E. B., Araújo, M., \& Machado, R. J. (2020). The roles of a Programme and Project Management Office to support collaborative university-industry R\&D. Total Quality Management \& Business Excellence, 31(5-6), 583-608. https://doi.org/10.1080/14783363.2018.1436963

Fernandes, G., Sousa, H., Tereso, A., \& O'Sullivan, D. (2021). Role of the Project Management Office in University Research Centres. Sustainability, 13(21), 12284. https://doi.org/10.3390/su132112284

Hermano, V., \& Martín-Cruz, N. (2016). The role of top management involvement in firms performing projects: A dynamic capabilities approach. Journal of Business Research, 69(9), 3447-3458. https://doi.org/10.1016/j.jbusres.2016.01.041

Kock, A., \& Gemünden, H. G. (2019). Project lineage management and project portfolio success. Project Management Journal, 50(5), 587-601. https://doi.org/10.1177/8756972819870357

Kwak, Y. H., Sadatsafavi, H., Walewski, J., \& Williams, N. L. (2015). Evolution of project based organization: A case study. International Journal of Project Management, 33(8), 1652-1664. https://doi.org/10.1016/j.ijproman.2015.05.004 
Lachowski, I. B. M. (2016). Project management office: a study on the benefits and limiting factors of its implementation. Thesis (Master in Entrepreneurship) - FEA/USP. São Paulo: University of São Paulo. São Paulo, Brazil. Advisor: Prof. PhD. Antonio Cesar Amaru Maximiano.

Lappi, T. M., Aaltonen, K., \& Kujala, J. (2019). Project governance and portfolio management in government digitalization. Transforming Government: People, Process and Policy, 13(2), 159-196. https://doi.org/10.1108/TG-112018-0068

Marconi, M. D. A., \& Lakatos, E. M. (2003). Fundamentos de metodologia científica. 5. ed.-São Paulo: Atlas.

Martinsuo, M., \& Geraldi, J. (2020). Management of project portfolios: Relationships of project portfolios with their contexts. International Journal of Project Management, 38(7), 441-453. https://doi.org/10.1016/j.ijproman.2020.02.002

Mosavi, A. (2014). Exploring the roles of portfolio steering committees in project portfolio governance. International Journal of Project Management, 32(3), 388-399. https://doi.org/10.1016/j.ijproman.2013.07.004

Müller, R., Drouin, N., \& Sankaran, S. (2019). Modeling organizational project management. Project Management Journal, 50(4), 499-513. https://doi.org/10.1177/8756972819847876

Müller, R., Pemsel, S., \& Shao, J. (2014). Organizational enablers for governance and governmentality of projects: A literature review. International Journal of Project Management, 32(8), 1309-1320. https://doi.org/10.1016/j.ijproman.2014.03.007

Müller, R., Zhai, L., \& Wang, A. (2017). Governance and governmentality in projects: Profiles and relationships with success. International Journal of Project Management, 35(3), 378-392. https://doi.org/10.1016/j.ijproman.2017.01.007

Oliveira, C., Tereso, A., \& Fernandes, G. (2017). PMO conceptualization for engineering and construction businesses. Procedia computer science, 121, 592-599. https://doi.org/10.1016/j.procs.2017.11.078

Oosthuizen, C., Grobbelaar, S. S., \& Bam, W. (2016). Exploring the link between PPM implementation and company success in achieving strategic goals: an empirical framework. South African Journal of Industrial Engineering, 27(3), 238-250. https://doi.org/10.7166/27-3-1635

Patanakul, P. (2015). Key attributes of effectiveness in managing project portfolio. International Journal of Project Management, 33(5), 1084-1097. https://doi.org/10.1016/j.ijproman.2015.01.004

Paulo, G. P. (2012). The use of auctions in expansion models for the electricity transmission network. Dissertation (Doctorate in Public Administration and Government) - EAESP/FGV. São Paulo: Getúlio Vargas Foundation 2012. Advisor: Prof. PhD Ciro Biderman.

Petro, Y., \& Gardiner, P. (2015). An investigation of the influence of organizational design on project portfolio success, effectiveness and business efficiency for project-based organizations. International Journal of Project Management, 33(8), 1717-1729. https://doi.org/10.1016/j.ijproman.2015.08.004

Rezende Oliveira, R., \& Cordeiro Martins, H. (2020). Project management office performance: divergence of the perceptions between academic instruction and professional experience. Innovar, 30(75), 119-134. https://doi.org/10.15446/innovar.v30n75.83261

Silva, L. H., Ghedine, T., Pereira, C. M. D., Lino, S. R. L., \& Tutida, A. Y. (2021). A management instrument for team performance evaluation. Revista Produção e Desenvolvimento, 7. https://doi.org/10.32358/rpd.2021.v7.511

Shou, W., Wang, J., Wu, P., \& Wang, X. (2021). Lean management framework for improving maintenance operation: Development and application in the oil and gas industry. Production Planning \& Control, 32(7), 585-602. https://doi.org/10.1080/09537287.2020.1744762

Tavares, S. R. (2015). Strategic alignment of project portfolio management. Thesis (Masters in Public and Business Administration) - EBAPE/FGV. Rio de Janeiro: Getúlio Vargas Foundation. Advisor: Prof. PhD Marcos Lopez Rego

Tereso, A., Ribeiro, P., Fernandes, G., Loureiro, I., \& Ferreira, M. (2019). Project management practices in private organizations. Project Management Journal, 50(1), 6-22. https://doi.org/10.1177/8756972818810966

Too, E. G., \& Weaver, P. (2014). The management of project management: A conceptual framework for project governance. International Journal of Project Management, 32(8), $1382-1394$. https://doi.org/10.1016/j.ijproman.2013.07.006

Ul Musawir, A., Serra, C. E. M., Zwikael, O., \& Ali, I. (2017). Project governance, benefit management, and project success: Towards a framework for supporting organizational strategy implementation. International Journal of Project Management, 35(8), 1658-1672. https://doi.org/10.1016/j.ijproman.2017.07.007 
DECLARATION OF CONTRIBUTIONS TO THE ARTICLE - CRediT

\begin{tabular}{|c|c|c|}
\hline ROLE & VCruz & FAraujo \\
\hline $\begin{array}{c}\text { Conceptualization - Ideas; formulation or evolution of overarching research goals and } \\
\text { aims. }\end{array}$ & $\mathrm{X}$ & $\mathrm{X}$ \\
\hline $\begin{array}{l}\text { Data curation - Management activities to annotate (produce metadata), scrub data and } \\
\text { maintain research data (including software code, where it is necessary for interpreting } \\
\text { the data itself) for initial use and later re-use. }\end{array}$ & $\mathrm{X}$ & \\
\hline $\begin{array}{l}\text { Formal analysis - Application of statistical, mathematical, computational, or other } \\
\text { formal techniques to analyze or synthesize study data. }\end{array}$ & $\mathrm{X}$ & $\mathrm{X}$ \\
\hline $\begin{array}{l}\text { Funding acquisition - Acquisition of the financial support for the project leading to } \\
\text { this publication. }\end{array}$ & $\mathrm{X}$ & $\mathrm{X}$ \\
\hline $\begin{array}{l}\text { Investigation - Conducting a research and investigation process, specifically } \\
\text { performing the experiments, or data/evidence collection. }\end{array}$ & $\mathrm{X}$ & \\
\hline Methodology - Development or design of methodology; creation of models. & $\mathrm{X}$ & $\mathrm{X}$ \\
\hline $\begin{array}{l}\text { Project administration - Management and coordination responsibility for the research } \\
\text { activity planning and execution. }\end{array}$ & $\mathrm{X}$ & \\
\hline $\begin{array}{l}\text { Resources - Provision of study materials, reagents, materials, patients, laboratory } \\
\text { samples, animals, instrumentation, computing resources, or other analysis tools. }\end{array}$ & $\mathrm{X}$ & $\mathrm{X}$ \\
\hline $\begin{array}{l}\text { Software - Programming, software development; designing computer programs; } \\
\text { implementation of the computer code and supporting algorithms; testing of existing } \\
\text { code components. }\end{array}$ & $\mathrm{X}$ & \\
\hline $\begin{array}{l}\text { Supervision - Oversight and leadership responsibility for the research activity } \\
\text { planning and execution, including mentorship external to the core team. }\end{array}$ & $\mathrm{X}$ & $\mathrm{X}$ \\
\hline $\begin{array}{l}\text { Validation - Verification, whether as a part of the activity or separate, of the overall } \\
\text { replication/reproducibility of results/experiments and other research outputs. }\end{array}$ & & $\mathrm{X}$ \\
\hline $\begin{array}{l}\text { Visualization - Preparation, creation and/or presentation of the published work, } \\
\text { specifically visualization/data presentation. }\end{array}$ & $\mathrm{X}$ & \\
\hline $\begin{array}{l}\text { Writing - original draft - Preparation, creation and/or presentation of the published } \\
\text { work, specifically writing the initial draft (including substantive translation). }\end{array}$ & $\mathrm{X}$ & \\
\hline $\begin{array}{l}\text { Writing - review \& editing - Preparation, creation and/or presentation of the } \\
\text { published work by those from the original research group, specifically critical review, } \\
\text { commentary or revision - including pre- or post-publication stages. }\end{array}$ & $\mathrm{X}$ & $\mathrm{X}$ \\
\hline
\end{tabular}

